This proceeding paper was presented as Invited Oral Presentation at Nutrition, Food Science and Technology 2018, April 16-18, Dubai-UAE

\section{Novel Applications in Nutrition and Food Science: Fortificated Vitamins and Polyphenols of Innovative Industrial Foods and Nutraceuticals}

\author{
Özlem TOKUŞOĞLU ${ }^{1,2}$ \\ ${ }^{1}$ Celal Bayar University, Engineering Faculty, \\ Department of Food Engineering, Manisa, Turkey \\ ${ }^{2}$ Dokuz Eylül University Technology Development Zone, \\ DEPARK Technopark, SPIL INNOVA Ltd.Şti, Izmir, \\ Turkey
}

\section{Abstract}

The necessity of fortificated bioactive vitamins carotenoids, and polyphenolic compounds (flavonoids etc.) has been accelerated the development of innovations in the food industry, generating the so-called "functional foods" and "nutraceuticals"; these are primary importance for human nutrition. Novel processing applications may influence the quality and effectiveness of mentioned nutrients including most fortificated vitamins (Vitamin C,A), carotenoids and phenolic bioactives. In this review content, Pulsed Electrical Field (PEF) processing effects on mentioned nutraceuticals including vitamin $\mathrm{C}$, Vitamin A, carotenoids and phenolics has been detailed approached.
Keywords: Bioactive Vitamins,

Polyphenols, Pulsed Electrical Field (PEF),

Nutraceutical

\section{Introduction}

Nutraceutical vitamins are micronutrients from food by-products that play an essential

role in nutrition, food science and technology. It has been determined that nutraceutical food powders as a sources of anticarcinogenic vitamins and carotenoids in medical genomics approach. Most fortificated vitamin C, Vitamin A and also precursor carotenoids as antioxidative defence system components and that of with gene regulation functions have been considered.

Vitamins are micronutrients of foods and beverages that play an essential role in human nutrition. The occurrence of the vitamins in the various groups of food is related to their water or fat-solubility. They comprise a diverse group of organic compounds that are nutritionally essential minor components.

Novel non-thermal technologies (e.g. ultrasounds, high-hydrostatic pressure-HHP, pulsed electric field-PEF) promise to treat foods without decomposing the nutritional constituents and sensorial properties that are normally affected during heat 
treatment. The implementation of novel technologies together with other trends and practices of the food industry (containing microencapsulation, food waste recovery, food by product based powders) have been brought new developments and state of the art in the industrial foods field.

\section{Vitamins and Phenolics as Fortifiers}

Vitamin function in vivo in several ways, including (a) as coenzymes or their precursors (niacin, thiamin, riboflavin, vitamin $\quad \mathrm{B} 6$, vitamin $\quad \mathrm{B}_{12}$, biotin, pantothenic acid, and folate; (b) as components of the antioxidative defense system (ascorbic acid, certain carotenoids and vitamin E); (c) as factors involved in genetic regulation (vitamin $\mathrm{A}$ and vitamin $\mathrm{D}$, vitamin $\mathrm{B} 6$, folate) is precious for human health and nutrition (Traber,2007; Gregory,1996; de Man,1999) (Figure 1.).

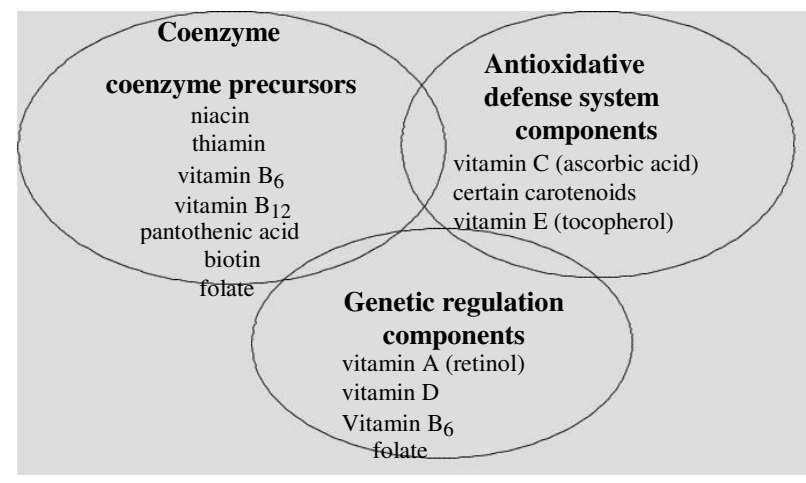

FIGURE 1. Vitamin function in vivo

Food is a very complex matrix made up of lots of many individual components including fat and water soluble vitamins that a group of essential organic molecules. Fat soluble (A,D,E,K) and water soluble vitamins (B group, C, biotin, pantothenic acid) in foods have been categorized as above-mentioned three groups from a biochemical standpoint (Figure 1.).

With developing of functional foods, nutraceuticals and dietary patterns, "dietary nutriome" (nutrient profile and composition) and genome health maintenance has been improved. Nutrigenomics based on genome healths is an emerging and recent important field of food nutritional science due to it is increasingly evident that optimal concentration of micronutrients for the prevention of genome damage is dependent upon genetic polymorphisms that alter the gene function involved directly or indirectly in DNA repair and metabolism. It has shown that above-average intake of certain micronutrients (i.e. vitamin $\mathrm{E}$, retinol, folate, vitamin $\mathrm{B} 6$ ) is associated with a reduced genome damage rate measured using the micronucleus assay (Fenech,2007).

Antioxidants quench free radicals via donating the phenolic $H$ and an electron. They exhibit variable degrees of efficiency for protection of human cells. Especially vitamin C (ascorbic acid) and certain carotenoids ( -carotene), when not esterified, have the ability to act as antioxidants (Gregory,1996). Recently, a great interest has been focused on 
antioxidant vitamins in foods, particularly owing to their likely role in the prevention of coronary heart diseases and cancer (Simon,1992; Gester,1991; German,1990)

It is determined that the physicological action of retinoids is expressed through nuclear receptors which can bind retinoids and regulate the expression of various genes. All transretinoic acid and 9-cis retinoic acid which are active metabolites of vitamin $\mathrm{A}$ are utilized as ligands for nuclear receptors (RAR, RXR), that results in regulation of the expression of various genes at the transcription level (Takase et.al, 1998, 2000).

\section{Novel Processing Effects on}

\section{Nutraceuticals}

Consumers around the world are better educated and more demanding in their identification and purchase of quality health-promoting foods. The food industry and regulatory agencies are searching for innovative technologies to provide safe and stable foods for their clientele. Thermal pasteurization and commercial sterilization of foods provide safe and nutritious foods that, unfortunately, are often heated beyond a safety factor that results in unacceptable quality and nutrient retention. Nonthermal processing technologies offer unprecedented opportunities and chal- lenges for the food industry to market safe, high-quality health-promoting foods. The development of nonthermal processing technologies for food processing is providing an excellent balance between safety and minimal processing, between acceptable economic constraints and superior quality, and between unique approaches and traditional processing resources (Zhang et al., 2011). Nonthermal food processing is often perceived as an alternative to thermal food processing; yet, there are many nonthermal preparatory unit operations as well as food processing and preservation opportunities and challenges that require further investigation by the food industry. Nonthermal technologies are useful not only for inactivation of microorganisms and enzymes, but also to improve yield and development of ingredients and marketable foods with novel quality and nutritional characteristics (Bermudez-Aguirre and Barbosa-Canovas, 2011).

\section{Effect of PEF Processing on Ascorbic} Acid (Vitamin C) and Carotenoids

A number of studies have proven the effectiveness of PEF technologies in achieving higher ascorbic acid (vitamin C) content in comparison with heat treatments. Vitamin $\mathrm{C}$ retention in a heat-treated $\left(90^{\circ} \mathrm{C}, 60 \mathrm{~s}\right)$ tomato juice was 
$79.2 \%$, whereas in a PEF-processed juice (35 $\mathrm{kV} / \mathrm{cm}$ for $1500 \mu \mathrm{s}$ in bipolar $4-\mu \mathrm{s}$ pulses at $100 \mathrm{~Hz}$ ), a $86.5 \%$ retention was attained just after processing (OdriozolaSerrano et al., 2008a). Consistently, vitamin $\mathrm{C}$ retention reported in a heattreated strawberry juice (94\%) was significantly lower than in a PEF-treated juice (98\%) (Odriozola et al., 2008b).

Most of the differences in vitamin results between PEF and heat treatments can be explained through the temperatures reached during processing. The concentration of vitamin $\mathrm{C}$ in thermally and PEF-processed juices gradually decreased with storage time. However, it has been demonstrated that vitamin $\mathrm{C}$ is better retained in PEF-treated juices than in thermally processed juices after 56 days of storage at $4{ }^{\circ} \mathrm{C}$ (Morales-de la Peña et al., 2010a; Odriozola-Serrano et al., 2008a,b).

Vitamin $\mathrm{C}$ juices in PEF juices also depend on PEF-processing factors and, thus, the lower the electric field strength, the treatment time, the pulse frequency, or the pulse width, the higher the vitamin $\mathrm{C}$ retention in orange (Elez-Martínez and Martín-Belloso, 2007), tomato (OdriozolaSerrano et al., 2007, 2008b), and strawberry juices (Odriozola-Serrano et al., 2009a).

Ascorbic acid is an unstable compound, which under less-desirable conditions, decomposes easily; hence, the milder the treatment, the better the vitamin $\mathrm{C}$ retention in juices. However, differences in vitamin $\mathrm{C}$ pressure stability during storage could be explained by the initial oxygen content and possible endogenous prooxidative enzyme activity. Bioavailability is defined as the proportion of the nutrients, bioactive compounds, or phytochemicals that are digested, absorbed, and metabolized throughout the normal pathway (Sánchez-Moreno et al., 2009). Drinking two glasses of PEF-treated or HP (high-pressure)-treated orange juice (500 $\mathrm{mL}$ /day) containing approximately $180 \mathrm{mg}$ of vitamin $\mathrm{C}$ was associated with a significant increase in plasma vitamin $\mathrm{C}$ concentration and a decrease in plasma levels of 8-epiPGF2 $\alpha$ (biomarkers of lipid peroxidation) (Sánchez-Moreno et al., 2003, 2004).

\section{Effect of PEF Processing on Carotenoids}

Recent studies have suggested that carotenoids content increases significantly after PEF processing compared to the untreated juice. Odriozola-Serrano et al. (2007) observed an enhancement of up to $46.2 \%$ in the lycopene-relative concentration of tomato juices after applying different PEF treatments (35 $\mathrm{kV} / \mathrm{cm}$ for $1000 \mu \mathrm{s})$. It has been 
hypothesized that thermal treatments may lead to an increase in some individual carotenoids, owing to greater stability, inactivation of oxidative and hydrolytic enzymes, and unaccounted moisture loss, which concentrates the sample (RodríguezAmaya, 1997). Nguyen and Schwartz (1999) suggested that homogenization and heat treatment disrupt cell membranes and protein-carotenoids complex, making carotenoids more accessible for extraction and probably more bioaccessible.

Recent studies also show a higher stability of carotenoids throughout storage in PEF-treated products compared to heattreated equivalents. PEF-processed tomato juices at $35 \mathrm{kV} / \mathrm{cm}$ for $1500 \mu$ s maintained higher contents of carotenoids (lycopene, neurosporene, and $\gamma$-carotene) through refrigerated storage than heat-processed juices at $90^{\circ} \mathrm{C}$ for $30 \mathrm{~s}$. The major cause of carotenoid losses in vegetable products is the oxidation of the highly unsaturated carotenoid structure (Tokusoglu et.al.,2015).

\section{Effect of PEF Processing on Phenolics}

Flavonoids are the most common and widely distributed group of plant phenolics. Among them, flavones,

flavonols, flavanols, flavanones, anthocyanins, and isoflavones are particularly common in fruits. Regarding the main flavanones identified in orange juice, HP treatments $\left(400 \mathrm{MPa} / 40^{\circ} \mathrm{C} / 1\right.$ min) increased the content of naringenin by $20 \%$ and the content of hesperetin by $40 \%$ in comparison with an untreated orange juice (Sánchez-Moreno et al., 2005). These results are in accordance with those obtained by other authors showing higher extraction of phenolic compounds due to $\mathrm{HP}$ processing. PEF processing $(35 \mathrm{kV} / \mathrm{cm}$ for $1500 \mu \mathrm{s}$ with $4-\mu \mathrm{s}$ bipolar pulses at 100 $\mathrm{Hz})$ and thermal treatments $\left(90^{\circ} \mathrm{C}, 30 \mathrm{~s}\right.$ and $90^{\circ} \mathrm{C}, 60 \mathrm{~s}$ ) did not affect phenolic content of tomato juices. Both PEF- and heattreated tomato juices undergo a substantial loss of phenolic acids (chlorogenic and ferulic) and flavonols (quercetin and kaempferol) during 56 days of storage at $4^{\circ} \mathrm{C}$. Caffeic acid content was slightly enhanced over time, regardless of the kind of processing, whereas PEF- and heattreated tomato juices underwent a substantial depletion of $p$-coumaric acid during storage.

The increase of caffeic acid in tomato juices after 28 days of storage could be directly associated with residual hydroxylase activities, which convert coumaric acid into caffeic acid (OdriozolSerrano et al., 2009). In strawberry juices, $p$-hydroxybenzoic content was enhanced slightly, but significantly after PEF processing $(35 \mathrm{kV} / \mathrm{cm}$ for $1700 \mu \mathrm{s}$ in bipolar $4-\mu$ s pulses at $100 \mathrm{~Hz}$ ) compared to 
the untreated juice, whereas ellagic acid was substantially reduced when the heat treatment was conducted at $90^{\circ} \mathrm{C}$ for $60 \mathrm{~s}$.

Anthocyanins are a widespread group of plant phenolic compounds that have been regarded as a natural alternative to replace synthetic food colorants. The content of individual anthocyanins significantly depended on the highintensity pulsed electric fields (HIPEF) treatment time and electric field strength applied during HIPEF processing of the strawberry juices. Anthocyanins were not affected by HIPEF processing when strawberry juice was treated at $22 \mathrm{kV} / \mathrm{cm}$. At electric field strengths from 27 to 32 $\mathrm{kV} / \mathrm{cm}$, it was observed that the lower the treatment time and electric field strength, the greater the anthocyanin retention. By the contrary, strawberry juices subjected to the most intensive treatment $(37 \mathrm{kV} / \mathrm{cm})$ exhibited the highest anthocyanins content (110-151\%) when the longest HIPEF treatment was conducted. It has been

reported that proanthocyanins are converted into anthocyanins after processing in acidic water-free conditions (Saint-Cricq de Gaulejac et al., 1999).

No significant differences in flavonol (kaempferol, quercetin, and myricetin) contents were obtained between fresh and treated strawberry juices; thus, these phenolic compounds were not affected by processing (Odriozola-Serrano et al., 2008b). The degradation of phenolic compounds during storage has been mainly related to the residual activity (RA) of polyphenol oxidase (PPO) and polyphenol peroxidase (POD) (Odriozola-Serrano et al., 2009).

\section{References}

de Man JM. 1999. Principles of Food Chemistry. Aspen Publishers,Inc. Gaithersburg, Maryland. p. 362-365; 355388. ISBN: 0-8342-1234-X

Elez-Martínez P., and Martín-Belloso O. 2007. Effects of high intensity pulsed electric field processing conditions on vitamin $\mathrm{C}$ and antioxidant capacity of orange juice and "Gazpacho", a could vegetable soup. Food Chemistry, 102, 201-209.

Fenech M. 2007. Nutrition and Genome Health. In Nutrigenomics-Opportunities in Asia. Tai ES, Gillies PJ (eds). Forum Nutr.Basel, Karger, 2007, vol 60, pp 49-65.

German I. 1990. Antioxidant Vitamins and Cardiovascular Diseases. Hoffmann-La Roche, Basel, Switzerland.

Gerster H. 1991. Potential role of carotene in the prevention of cardiovascular disease. Int J Vitam Nutr Res, 61, 277-291.

Gregory III JF. 1996. Vitamins. In Food Chemistry. Fennema O.R. (eds). Marcel Dekker, Inc. New York. p.531-616. ISBN: 0-8247-9346-3. 
Morales-de la Peña M., Salvia-Trujillo L., Rojas-Graü M.A., and Martín-Belloso O. 2010a. Impact of high intensity pulsed electric field on antioxidant properties and quality parameters of a fruit juic-soymilk beverage in chilled storage. $L W T-F o o d$ Science and Technology, 43, 872-881.

Nguyen M.L., and Schwartz S.J. 1999. Lycopene: Chemical and biological properties. Food Technology, 53(2), $38-45$.

Odriozola-Serrano I., Aguiló-Aguayo I., Soliva-Fortuny R., Gimeno-Añó V., and Martín-Belloso O. 2007. Lycopene, vitamin $\mathrm{C}$, and antioxidant capacity of tomato juice as affected by high-intensity pulsed electric fields critical parameters. Journal of Agricultural and Food Chemistry, 55, 9036-9042.

Odriozola-Serrano I., Soliva-Fortuny R., and Martín-Belloso O. 2008. Phenolic acids, flavonoids, vitamin $\mathrm{C}$ and antioxidant capacity of strawberry juices processed by high-intensity pulsed electric fields or heat treatments. European Food Reserach Technology, 228, 239-248.

Odriozola-Serrano I., Soliva-Fortuny R., and Martín-Belloso O. 2008a. Changes of health-related compounds throughout cold storage of tomato juice stabilized by thermal or high intensity pulsed electric field treatments. Innovative Food Science and Emerging Technologies, 9, 272- 279.

Odriozola-Serrano I., Soliva-Fortuny R., Gimeno-Añó V., and Martín-Belloso O. 2008b. Modeling changes in health-related compounds of tomato juice treated by high-intensity pulsed electric fields. Journal of Food Engineering, 89, 210-216.

Odriozola-Serrano I., Soliva-Fortuny R., Hernández-Jover T., and Martín-Belloso O. 2009. Carotenoid and phenolic profile of tomato juices processed by high intensity pulsed electric fields compared with conventional thermal treatments. Food Chemistry, 112, 258-266.

Odriozola-Serrano I., Soliva-Fortuny R., and Martin-Belloso O. 2009a. Impact of high-intensity pulsed electric fields variables on vitamin $C$, anthocyanins and antioxidant capacity of strawberry juice.

LWT-Food Science and Technology, 42, 93-100.

Saint-Cricq de Gaulejac N., Vivas N., de Freitas V., Bourgeois G. 1999. The influence of various phenolic compounds on scavenging activity assessed by and enzymatic method. Journal of Scientific Food Agriculture, 79, 1081-1090

Sánchez-Moreno C., Cano M.P., De Ancos B., Plaza L., Olmedilla B., Granado F., Martín A. 2003. High-pressurized orange juice consumption affects plasma vitamin $\mathrm{C}$, antioxidative status and inflammatory markers in healthy humans. Journal of Nutrition, 133, 2204-2209.

Sánchez-Moreno C., Cano M.P., De Ancos B., Plaza L., Olmedilla B., Granado F., Elez-Martínez P., Martín-Belloso O., and Martín A. 2004. Pulsed electric fields processed orange juice 
consumption increases plasma vitamin $\mathrm{C}$ and decreases $\mathrm{F} 2$-isoprostanes in healthy humans. Journal of Nutritional Biochemistry, 15, 601-607.

Sánchez-Moreno C., Plaza L., Elez Martínez P., de Ancos B., MartínBelloso O., and Cano P. 2005. Impact of high pressure and pulsed electric fields on bioactive compounds and antioxidant capacity of orange juice in comparison with traditional thermal processing. Journal of Agricultural and Food Chemistry, 53(11), 4403- 4409.

Sánchez-Moreno C., De Ancos B., Plaza L., Elez-Martínez P., and Cano M.P. 2009. Nutritional approaches and health-related properties of plant foods processed by high pressure and pulsed electric fields. Critical Reviews in Food Science and Nutrition, 49, 552- 576 .

Simon JA. 1992. Vitamin $\mathrm{C}$ and cardiovascular disease: a review. J.Am.Coll.Nutr., 11, 107-125.

Takase S, Tanaka K, Suruga K, Kitagawa M, Igarashi M, Goda T. 1998. Dietary fatty acids (Fas) are possible key determinants of cellular retinol-binding protein II gene expression. American Journal of Physiology, 274, G626-G632.

Takase S, Suruga K, Goda T. 2000. Regulation of vitamin A metabolismrelated gene expression. British Journal of Nutrition, 84(2), S217-S221.

Tokuşoğlu Ö., Odriozolla I., Martin O. 2015. "Quality, Safety And Shelf Life Improving in Fruit Juice by Pulsed Electric Fields" [Chapter 18- Part III. Improving Food Quality with Pulse Electric Field (PEF)
Technologies]. p.385-411. In "Improving Food Quality with Novel Food Processing Technologies". Book Ed. Özlem Tokuşoğlu \& Barry G. Swanson. CRC Press, Taylor \& Francis Group, Boca Raton, Florida,USA. 462 page. ISBN 9781466507241.

Traber MG. 2007. Vitamin E. In Handbook of Vitamins. Zempleni J, Rucker RB, Mc Cormick DB, Suttie JW.4 ${ }^{\text {th }}$ edition. p:153174.CRC Press, Taylor \& Francis Group, Boca Raton, FL. ISBN-13: 978-0-84934022-2. 